Vol. 3, No. 2, 2016

UDC 330.341.1

N. Stanasyuk

Ph.D. in Economics, Associate Professor,

Lviv Polytechnic National University

\title{
FORMATION OF MECHANISM OF INDUSTRIAL POTENTIAL DEVELOPMENT STATE ADMINISTRATION
}

\begin{abstract}
The article reveals the substance of the category of "mechanism" and analyzes approaches to its formation as an element of the management system. Conceptual principles of management mechanism of industrial potential development using subject-object approach are defined. There are identified the elements of the state administration mechanism based on microand macroeconomic "resource - result" models and on the receipt of the best possible result with the optimal combination of different functional blocks. Stage-bystage methodology of its formation based on programpurpose approach is offered.
\end{abstract}

Keywords: mechanism, intra-business management, state administration, industrial potential, development.

Formulation of the problem. The key problem of modern economic development of the country is finding the way out of the protracted economic crisis. Thus, structural and technical modernisation of industry is considered as a strategic vector of future economic growth that must become the basis for future positive changes in the economy. Hence, the industrial potential becomes the foundation for structural improvement of national economy, and its development will assist the rapid accumulation of scientific and technological innovations that will lead to the formation of innovative economy as a transitional period to post-industrial type of development.

With the account of the strategic role of industrial potential, there arises the necessity of effective state administration able to provide progressive changes in its development. Formation of management mechanism, selection of its basic elements and adjustment of the balanced interrelation between them will increase the management quality, effective use of present potential and achievement of strategic vectors of economic development considering the processes of European integration and world globalization on the whole.

\section{Analysis of recent research and publications}

Conceptual principles of state administration are widely highlighted in works of native and foreign researchers. According to the well-known American philosopher F. Fukujama, it was just the reduction of the role of the state during the last years that resulted in world crises [1, p. 20]. O. V. Raevneva states that the most active element of a management system is a mechanism [2, p. 225]. O. Korotych believes that "a certain management mechanism is the tool for realization of purposeful transformations" [3, p. 25].

A considerable contribution to the development of a toolset of management mechanism has been made by O. Kuzmin and O. Melnyk who suggested distinguishing five general functions of management: planning, organizing, motivating, controlling, and regulating, which are performed with the account of specific features of the management object [4, p. 58]. However, most current scientific research focuses on the development of management mechanism at the local level (an economic entity - an enterprise [211]), while the issues forming the state administration mechanism of industrial potential development at higher hierarchical levels remain poorly studied.

The objective of the research is to justify the content of the mechanism of state administration of industrial potential development, and to identify its structural elements as well as develop methodology of its formation.

It is worth noting that scientists and practitioners interpret the concept of "mechanism" differently. It is believed that this term appeared due to the development of engineering sciences. Taking into account the content of this concept as an economic category, it is possible to distinguish three basic approaches to its determination:

- as a means, an instrument of influence;

- as a system of interrelated elements;

- as a sequence of processes.

Zh. M. Balabaniuk states that a mechanism is "the system, which determines the order of any type of activity [5, p. 190]". Compliance with the 


\section{N. Stanasyuk}

order is achieved due to the clearly defined purpose, which is a basic element of the mechanism. Besides the purpose, there are identified functions, methods, principles, instruments and levers as elements of mechanism, the application of which allows achieving the defined purposes. Using the subject-object approach it is possible to divide all the elements of the system into the elements of a managing subsystem and the elements of a managed system. The authors of the work [6, p. 178] suggest dividing a mechanism structurally into two blocks: a management system and a target subsystem, within the limits of which it is possible to determine management effectiveness. Such a division allows separating clearly the key elements and arranging the relations between them. This makes the system more balanced and improves the quality of management.

In the context of our research, it is the development of industrial potential that is considered to be the managed subsystem, which, under modern conditions, requires the immediate interference of the state in order to regulate the structural disproportions and to establish the balanced interaction within the system. As to the subject of management, it should be examined at some hierarchical levels: international, national, regional, and local. Levels of management are characterized by certain subordination related to the differentiation of functions and identification of various areas of responsibility.

O. Fedorchak defines the management mechanism as a system having a certain structure, methods, leverages and instruments of influence on the object of management [8]. The purpose is achieved just through the functional elements of the mechanism, which are shown in their general form in Fig. 1.

It is worth pointing out that though the mechanism's division into elements is typical, the internal content of these elements considerably depends on the essence of the object. So, taking into account the specific features of the object being managed, we suggest distinguishing the following elements of the mechanism of state administration of industrial potential development (Table 1).

Mechanism, as a whole, is a harmonious combination of elements accounting specific features of modern stage of economic development of the country and its strategic goals.
First of all, it is possible to estimate the scale and possibility to use resources on the basis of formation of the system of input and output growth indicators. The input parameters answer the question what we have, while the output parameters - where it is better to use the available resources.

A macro-environment is characterized by considerable changeability and causes changes in the size of industrial potential by input and output criteria. Thus, components of industrial potential are variables dependant on the factors of influence, which are to be reasonably united into groups depending on the nature of changes they cause, that will allow creating a by-element structure of macro environment with the effective system of relations. Under these conditions, development of industrial potential is the result of joint influence of integration of institutional and legal, economic, social and cultural, geopolitical, scientific and technological, natural and ecological environment.

Optimization of industrial capacity should be oriented to the needs of the internal market, taking into account the requirements of the industrial modernization and global integration processes with the aim of entering foreign markets with the domestic industrial production. As Kindzerskyi Yu.V. states, "tactics of structural changes should be extracted from the need to focus on specific segments of domestic and foreign markets" [12, p. 533]. Thus, both current state of industry and future targets should be taken into account now.

There was a considerable increase of research concerning spatial economy during the last decade. Space is no more limited only to the territorial aspects; it gained complexity with regard to the allocation of its structural elements. Based on the systems approach, the model of multidimensional space, offered by M. M. Gabriel, includes five constituents (person, function, conditions, geometry, time) [13, p.533]. The issues of spatial organization of industrial production are more often reduced today to creation of industrial clusters as an innovative form of organizing the national economy. M. Porter characterizes industrial clusters as groups of interdependent enterprises, institutions, organizations that can cooperate and are geographically concentrated [14, p. 149]. The cluster model of industrial potential development will allow to get a synergistic effect as a result of integration of interests of different participants with a common goal. 

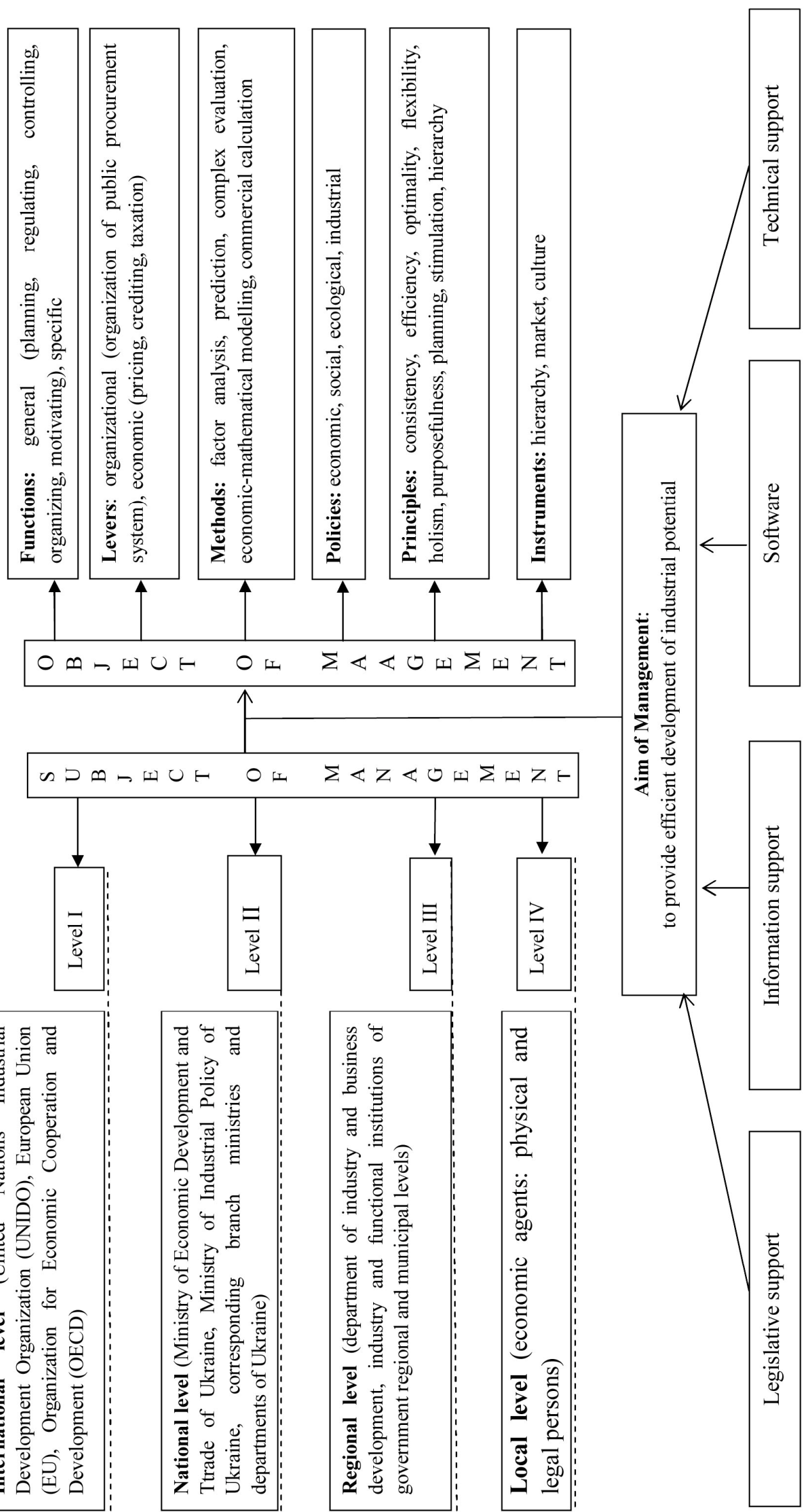

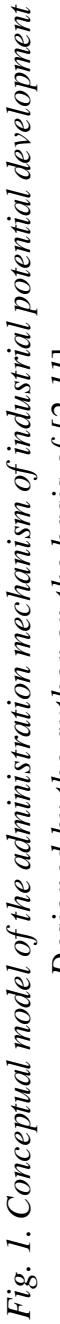
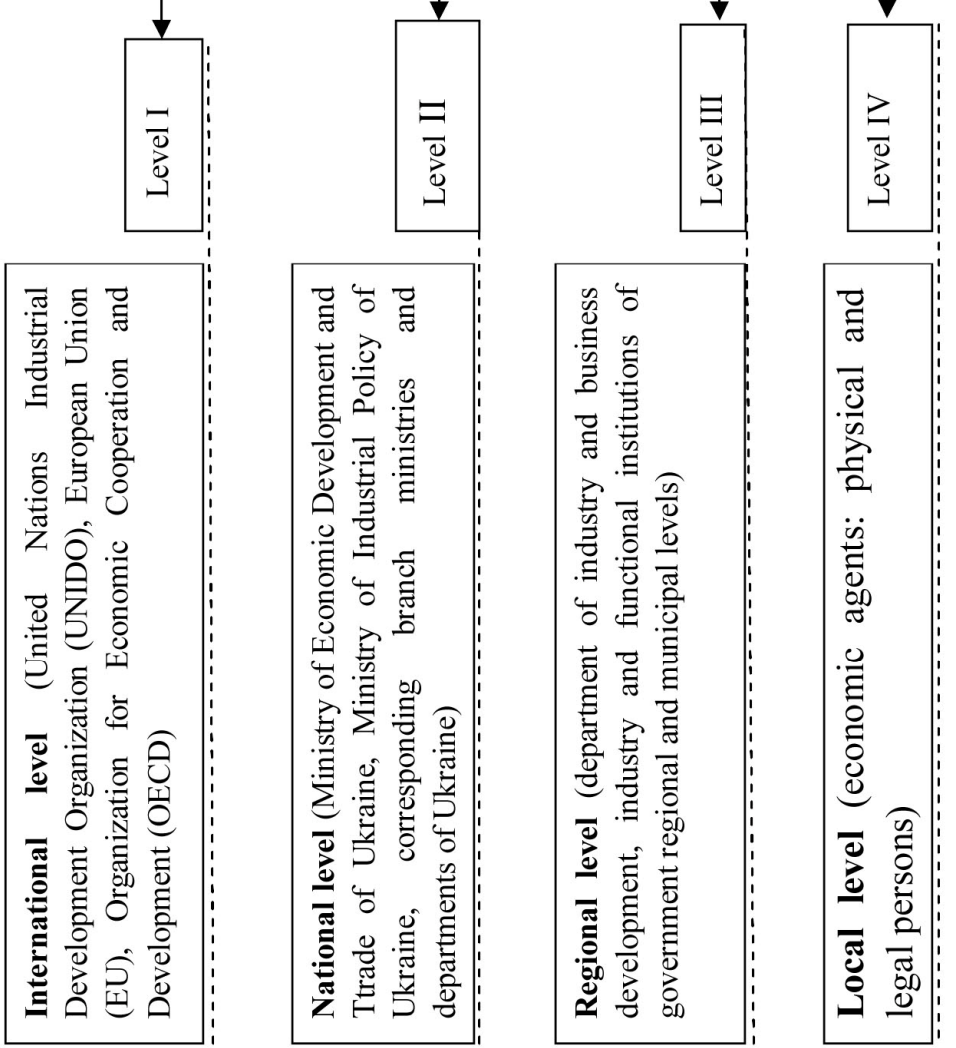


\section{N. Stanasyuk}

Table 1

\section{Specific Elements of the Mechanism of State Administration of Industrial Potential Development}

\begin{tabular}{|l|l|}
\hline \multicolumn{1}{|c|}{ Elements of the mechanism } & \multicolumn{1}{|c|}{ Essence of the mechanism elements } \\
\hline $\begin{array}{l}\text { Formation of input and output an output } \\
\text { indicators of industrial potential } \\
\text { development }\end{array}$ & $\begin{array}{l}\text { Determination of indexes, which characterize input and } \\
\text { indicators in order to fulfil complex evaluation of the level of industrial } \\
\text { potential development }\end{array}$ \\
\hline $\begin{array}{l}\text { Analysis of the factors influencing the } \\
\text { development of the industrial potential } \\
\text { development }\end{array}$ & $\begin{array}{l}\text { Establishment of cause and effect relationship between the indicators } \\
\text { that represent the factors of influence and the indicators that } \\
\text { characterize the development of industrial potential }\end{array}$ \\
\hline Structuring the industrial potential & Optimization of structural development of the industrial potential \\
\hline $\begin{array}{l}\text { Spatial organization of industrial } \\
\text { potential }\end{array}$ & $\begin{array}{l}\text { Identification of industrial clusters and analysis of their influence on the } \\
\text { development of industrial potential }\end{array}$ \\
\hline Introduction of innovations & $\begin{array}{l}\text { Assessment of possibility of certain type of activity to produce science- } \\
\text { intensive products }\end{array}$ \\
\hline Development support & $\begin{array}{l}\text { Formation of the support system (infrastructure, information, marketing, } \\
\text { logistic) to ensure functioning of basic potential elements (industrial and } \\
\text { economic, social and labour, financial and investment and innovative } \\
\text { components) }\end{array}$ \\
\hline $\begin{array}{l}\text { Establishment of relationships between } \\
\text { management bodies }\end{array}$ & $\begin{array}{l}\text { Allocation of local, regional, and national priorities in development and } \\
\text { differentiation of powers }\end{array}$ \\
\hline $\begin{array}{l}\text { Means, ways, and sources of attracting } \\
\text { resources }\end{array}$ & $\begin{array}{l}\text { Methods and techniques of state administration: preferential bank loans, } \\
\text { tax benefits, organization of public contracts, investments attraction etc. }\end{array}$ \\
\hline Effectiveness & $\begin{array}{l}\text { A comparison of the actual performance with the planned one } \\
\text { (predicted) }\end{array}$ \\
\hline Efficiency & Comparison of the results obtained with the resources used \\
\hline
\end{tabular}

\section{Improved by the author}

Taking into account rapid development of scientific and technical progress as a basic factor of forming innovative economy, production of scientifically-intensive goods is the guarantee of successful economic development of the state. As a result, one of the main tasks of state governance is formation of the national innovative system, in the scopes of which realization of specific functions involves taking into account requirements of the economy of knowledge. Just its elements provide promotion of the innovative idea to the market, cause technological changes in the structure of industrial potential in order to form higher technological modes by increasing the share of high- and medium technology industrial manufacturing.

Distinguishing securing elements is, first of all, connected with the necessity of creating suitable conditions for functioning of the basic components of the industrial potential. It is worth noting that development of industrial potential today is not possible without formation of the objects of social, market and innovative infrastructure.
According to the common aim, subjects of management realize administrative influences through the system of regulators. Elements under their influence change their state, acquiring more perfect forms. In case of finding out negative deviations, the role of regulators is reduced to their removal and regulation in order to achieve the desirable result. That is, there is a feed-back between regulators and the objects of management that involves taking into account the reaction of other mechanism constituents to changes in the system of regulation.

Interrelation between the management bodies is based on chain dependence and provides direct as well as indirect influence. The essence of interrelation is reduced to setting the only development vector both on national and on regional and local levels.

The expected results of the mechanism realization are increase of industrial production capacity, expansion of markets, removal of structural disproportions of the development and creation of progressive technological 


\section{Formation of Mechanism of Industrial Potential Development State Administration}

structure of industrial potential in order to set up the innovative development model. Efficiency is the mechanism implementation quality criterion and is determined by the possibility of obtaining added gross output per unit of spent resources.
Taking into account the conceptual approach to the process of management based on a programaimed method, we suggest specifying the following stages in the process of forming the mechanism of state administration of industrial potential development (Fig. 2).

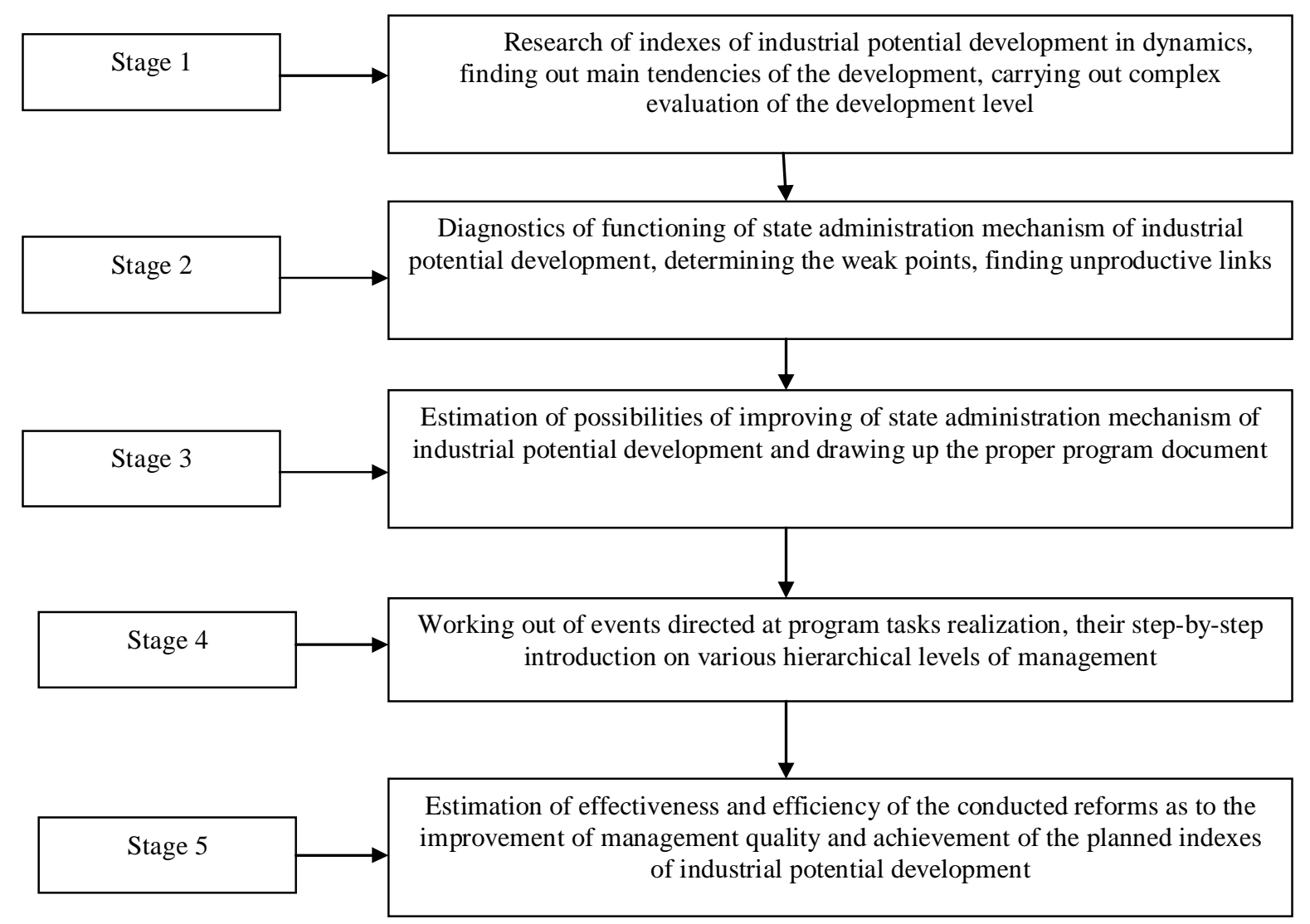

Fig. 2. Stages of forming the mechanism of state administration of industrial potential development Improved by the author

\section{Conclusions and perspectives for further research}

Summing up the defined conceptual basis and paradigms done by scientists, the mechanism of state administration of industrial potential development should be referred to as a multicomponent system of influence formed by subjectobject approach through balanced combination of functional blocks united by a common purpose that provides the achievement of the desirable result. The distinguished blocks are interdependent, that means that occurrence of changes in one block unavoidably leads to changes in another one, it being a component of a single system. Keeping to the sequence of the defined stages of forming the state administration mechanism of industrial potential development will allow implementing the "resource-result" model that will promote the improvement of the management quality.

Improvement of the mechanism must be carried out towards setting up social responsibility of the authority for the consequences of the conducted reforms; establishing a control institution that would monitor implementation of the set tasks; introducing a quarterly accounting statement about the results; increasing informative awareness of population. These directions will be expanded in further scientific research.

\section{References}

1. Fukuyma F. State - Bulding. Governance and Work Order the Twenty - First Century / 


\section{N. Stanasyuk}

F. Fukuyma. - [S.p.]: Lnd, Profile Books, 2004. P. 20.

2. Raêvnêva O. V. Upravlínnya rozvitkom pídpriêmstva: metodologíya, mekhanizmi, modeli: monografíya / O. V. Raêvnêva. - Kharkív : VD "ÍNZHEK", 2006. - 496 s.

3. Korotich O. B. Derzhavne upravlínnya regional'nim rozvitkom Ukraini: monografíya. Kharkiv : Vidavnitstvo KharRÍDU NADU "Magíst", 2006. - $220 \mathrm{~s}$

4. Kuz'mín O. $\hat{E}$. Osnovi menedzhmentu. / O. Ê Kuz'mín, O. G. Mel'nik. - K. : Akademvidav, 2007. - 464 s.

5. Balabanyuk ZH. M. Mekhanízm upravlínnya organizatsiêyu: sutnist' ponyattya ta propozitsii shchodo otsinki yogo yefektivností I ZH. M. Balabanyuk // Visnik Khmel'nits'kogo natsional'nogo universitetu. - 2011. - No. 5 (T.1). S. 190-194.

6. Markína Í. A. Organizatsíyno-yekonomíchniy mekhanizm upravlínnya informatsíynim potentsialom pídpriêmstva / Í. A. Markína, M. Í. S'omich, D. V. Dyachkov // Yekonomíchniy forum. - 2016. - No. 2. - S. 175-181.

7. Smachilo Í. Í. Printsipi formuvannya ta struktura mekhanizmu upravlínnya stalim rozvitkom pídpriêmstva / Í. Í. Smachilo // Yekonomíka rozvitku. - 2013. - No. 3. - S. 79-82.

8. Fedorchak O. Klasifikatsíya mekhanizmív derzhavnogo upravlínnya / O. Fedorchak // Naukoviy vísnik "Demokratichne vryaduvannya". - 2008.
Vip. 1. - Rezhim dostupu do zhurnalu: http://www. lvivacademy.com/vidavnitstvo_1/visnyk8/index.html

9. Filipishin I. V. Mekhanizm upravleniya razvitiyem promyshlennogo predpriyatiya / I. V. Filipishin // Yekonomíka promislovostí. 2011. - No. 4. - S. 220-227.

10. Kharchenko $V$. A. Mekhanizm formuvannya sistemi strategíchnogo upravlinnya rozvitkom promislovogo pídpriêmstva / V. A. Kharchenko // Yekonomíka promislovostí. - 2014. - No. 4 (68). S. 97-104.

11. Chechin O. P. Mekhanizm formirovaniya strategii razvitiya promyshlennogo predpriyatiya / O. P. Chechin // Vestnik Samar skogo gos. tekhn. un-ta. Ser .: Ekon. nauki. - 2014. - No. 1 (11). S. 46-49.

12. Kindzers'kiy Yu. V. Promislovist' Ukraíni: strategíya $i$ politika strukturno-tekhnologíchnoi modernizatsii : monografíya / Yu. V. Kindzers'kiy. $K$.: DU "Ínstitut yekonomíki ta prognozuvannya" NAN Ukraini, 2013. - 536 s.

13. Gabrel' M. M. Prostorova organizatsíya mistobudivnikh sistem: monografiya / M. M. Gabrel'. - K. : Vidavnichiy dim A.S.S., 2004. - $400 \mathrm{~s}$.

14. Porter M. E. Council of Competitiveness and Monitor Group, Clusters of Innovation Initiative: Regional Foundations of U.S. Competitiveness / M. E. Porter. - Washington DC, USA: Council of Competitiveness, 2000. - P. 149-164. 